\title{
Internationalization of Culture through Traditional Arts: A Case of Japanese SMEs
}

\author{
GLORIA GARCIA
}

\begin{abstract}
There are two important subjects concerning internationalization strategies that are of interest to academia, the business community and society in general. The first one is internationalization of small and medium-sized enterprises (SMEs); the other one is internationalization of local cultures. This article provides insights into the specific internationalization strategies used by Japanese SMEs to export traditional arts to foreign markets, focusing on Japanese pottery for the tea ceremony. SMEs encounter difficulties concerning limited resources in their internationalization process, but what is the situation of SMEs whose business activity is linked to indigenous cultural factors? The findings have been obtained from in-depth interviews with pottery artists as well as qualitative analysis of websites and other sources and they suggest a new previous phase in the export of products with a cultural meaning. I called this phase the 'reverse prior phase' and I argue that it might be a suitable way to start the internationalization process for Japanese traditional arts.
\end{abstract}

Keywords: internationalization strategies, Asian SMEs, cultural aspects as differentiation, Japanese culture.

\section{Introduction}

Internationalization is a process companies follow to obtain growing revenues from foreign markets. Over the last few decades this process has been increasing due to the fall of trade barriers and other factors such as the development of information technologies and transport improvements, which in turn have reduced the costs of exporting. These factors have helped small and medium-sized companies (SMEs) take part in the internationalization process (Rugman \& Collinson 2009).

Exporting is the most common internationalization strategy used by SMEs, but not the only one. SMEs can employ other internationalization strategies such as importing, turnkey projects in foreign markets, international cooperation agreements with foreign SMEs (Rugman \& Collinson 2009; Hill 2007) or foreign direct investments (FDI) (Rug- 
man \& Verbeke 2009), from the beginning of their internationalization or later, to consolidate their exporting position (Garcia 2012). When exporting is not possible, for example because of trade barriers or commercial obstacles, it can be useful to make a manufacturing agreement with a foreign SME partner or use FDI to solve the obstacles of the foreign market. These, however, are difficult solutions for most SMEs.

Whereas these conventional internationalization strategies are suitable for products that are very similar to each other, manufactured in large quantities and commonly used, the question arises as to whether they would also work for products with cultural factors ingrained in them. This article tries to answer this question by focusing on the case of SMEs that produce pottery for the Japanese tea ceremony. This kind of pottery is considered special for a number of reasons: (1) it is made by master potters using Japanese traditional methods; (2) it is produced in very limited quantities; (3) each piece is unique; (4) it is fired in a special type of kiln; (5) the potters are not able to control the final result of the work but it is nature that finishes it, covering the surface with natural ash glaze produced by the burning of wood; and (6) its aesthetic shows the Zen characteristics of asymmetry (irregular), simplicity (not smooth), emptiness (not too ornate) and harmony with nature.

To answer the previous question, the following three main objectives will be pursued. First, to explore the internationalization strategies followed by master pottery artists organized in SMEs in Shigaraki, Japan. Considering both the peculiar aesthetics of this kind of pottery and the Japanese cultural factors inherent in it, the main question is, how can Japanese pottery for the tea ceremony be internationalized? The second objective is to study the origin and importance of the cultural factors inherent in these pottery objects for the tea ceremony. These goods are not 'common goods'. Additionally, they are combined with local and cultural factors particular to them, to show the influence of Zen principles on this specific kind of pottery. The third objective is to examine whether the export of these products leads to the internationalization of Japanese culture.

In this research I have identified a new way of initiating the internationalization process, which I call the 'reverse prior phase', since the fostering activities are usually undertaken in foreign markets to educate retailers and customers to appreciate these unique and culturally specific products. As discussed later, this prior phase isn't the same as 
passively exporting or selling domestically; on the contrary, it involves several activities that are better done at the local production sites.

The article begins with a summary of conventional internationalization strategies. Next, Japanese traditional arts and the origin and importance of their ingrained cultural factors are examined. Then the SMEs studied and the research methodology are described. Finally, the findings are presented and discussed, followed by various limitations of the study.

\section{Internationalization Strategies of SMEs}

SMEs can choose one of three main entry strategies in international markets: exports, foreign direct investment (FDI), and contractual agreements such as license or franchise agreements. Exporting is the most common internationalization strategy employed by SMEs. Exporting and importing are trade strategies that consist of sending out or bringing goods and services into a country (Daniels, Radebaugh \& Sullivan 2010). Export strategies can be direct, through intermediaries such as commercial agents or distribution companies located in a foreign country or organized in alliance with other local SMEs in an exporting consortium (Su \& Poisson 2000). In all of these types of exporting, product information and promotion activities are done in the receiver country or by using website marketing. These techniques are useful to promote common goods but are less useful for little-known products that contain inherent cultural meanings.

Another entry strategy is FDI. Following the OECD definition, FDI reflects the aim of obtaining a lasting interest by a resident entity of one economy (direct investor) in an enterprise that is resident in another economy (the direct investment enterprise). 'Lasting interest' implies the existence of a long-term relationship between the investor and the investment enterprise and a significant degree of influence on the management of the latter. ${ }^{1}$ Krugman and Obstfeld define FDI as '...international capital flows in which a firm in one country creates or expands a subsidiary in another' (2000: 159). There is thus an important difference between FDI and portfolio investment, since FDI involves not only the transfer of resources but also the acquisition of control. In the case of FDI, SMEs most often use commercial investment, since this type requires less capital than manufacturing FDI (Holmlund, Kock \& Vanyuhin 2007; Lu \& Beamish 2006).

Contractual agreements such as franchising, subcontracting, licens- 
ing or management contracts are the third type of internationalization strategies by which an SME cooperates with other SMEs located in a foreign market. ${ }^{2}$

No matter which internationalization strategy is chosen, some of the main barriers to the internationalization of SMEs are: identifying international business opportunities, limited information to locate markets and the inability to contact potential overseas customers. ${ }^{3}$ Additionally, consumers usually prefer to buy products that are known by them and thus retailers are more willing to stock and display the products that people want. Therefore, SMEs producing goods with ingrained cultural elements that are unknown to people in foreign markets will perhaps not be able to provide information about these products and their characteristics in a foreign target market, thus making exporting more difficult.

\section{Japanese Traditional Arts and the Origin and Importance of their Implicit Cultural Factors}

To understand these pottery-producing SMEs, I begin by describing some of the main elements of the production of pottery for the tea ceremony produced in Shigaraki, a town located in Kōka District, province of Shiga, in Japan. These elements can be divided into two main groupings: one concerning the production process for making this kind of pottery and the other about the influence of Zen principles in this particular product. Both main groupings have implications for the internationalization strategies that the individual producer follows.

According to literature on Japanese culture (Suzuki 2009; Tanaka 2000), Zen principles have been the main influence on the formation of Japanese aesthetics and traditional arts such as calligraphy (shodō), pottery, the tea ceremony (chadō), flower arranging (ikebana) and gardenmaking (karesansui). Simplicity, asymmetry, emptiness and harmony with nature are some of the characteristics that define the Japanese aesthetics emanating from Zen (Suzuki 2009; Juniper 2003). This is important for the present research as this kind of aesthetic is related to cultural facts intrinsic to the pottery for the tea ceremony and because these implicit characteristics are extremely difficult to transmit to people from other cultures (Yanagi 1989).

The close relation between Zen and Japanese pottery for the tea ceremony has its origin in the fifteenth century, at the beginning of a style known as Wabicha. Since then, Zen philosophy has influenced not only 
the ritual and aesthetics of this style of tea ceremony but also its underlying ideas. The Zen priest Murata Shukō (1422-1502) applied the Zen philosophy to the tea ceremony and later successive Zen monks have been developing and further implementing this particular style. Finally, in the sixteenth century, Sen no Rikyū (1521-1591) further developed these ideas and established the Wabicha tea ceremony style that involves a very small, simple and quiet tea room combined with rather rough and irregular tea pottery bowls. In this way, Shukō Murata was the first tea master who appreciated the simple beauty of Shigaraki pottery and selected Shigaraki pottery as the most appropriate form for tea utensils because it incorporated the Japanese concept of beauty called wabi-sabi. Wabi connotes simplicity, asymmetry, austerity, naturalness, profound subtlety and unconditional freedom. Sabi can likewise be understood as restrained refinement and lustre. The natural appearance of this pottery reflects these principles and from this moment on the master potters from Shigaraki began to produce pottery for the tea ceremony. Basically, the Wabicha pottery was established when tea masters appreciated the beauty of pottery objects containing the Zen characteristics of simplicity (wabi) and imperfection (shibui). However, this pottery is different from ordinary pottery used by people in general since the specific pottery used in the tea ceremony must transcend its outward rough appearance and evoke a notion of simplicity, emptiness and asymmetry as well as a harmonic relationship with nature. These Zen characteristics let each observer perceive a beauty not previously displayed before him, '... a kind of beauty that makes an artist of the viewer' (Yanagi 1989: 124). This pottery shows an irregular and uneven texture because of the ash-glazed surface, which differs from other types of pottery such as the well-known smooth and bright surface of Chinese porcelain (Juniper 2003). It is perhaps this unusual beauty that makes it difficult to understand and appreciate the intrinsic imperfect beauty of this pottery, a difficulty that is reinforced when one does not know the underlying philosophy.

Shigaraki pottery is characterized by an uneven surface and irregular contours because the ash and mineral glaze on the surface and by the colours obtained after firing. The natural ash glaze is the result of firing in a type of kiln called Anagama, using wood as fuel. At present, Anagama is the only type of kiln used in Shigaraki to produce pottery for the tea ceremony because of the natural appearance obtained with it. Every potter has their own kiln design and their own way of firing that they have learnt and mastered over many years of trial and error, since the old traditional techniques have been lost. 


\section{SMEs Producing Tea Ceremony Pottery by Master Potters}

The ceramic sector of Shigaraki is made up of large companies producing industrial ceramics as well as SMEs producing pottery with traditional methods. As shown in Figure 1, there are approximately 100 potters located in Shigaraki town who work with traditional methods, ${ }^{4} 44$ of whom are pottery masters that have received the official title 'Master of Traditional Arts' (Dentō Kōgeishi); nine of them are considered the better producers of Shigaraki pottery for the tea ceremony.

FIGURE 1: Producers of Shigaraki's Pottery

\begin{tabular}{|l|c|}
\hline Big Companies & $\begin{array}{c}100 \text { Traditional Methods Potters } \\
44 \text { Pottery Masters }\end{array}$ \\
\hline Industrial Ceramic & 9 Pottery Artists Tea Ceremony \\
\hline
\end{tabular}

Unlike the European Union definition, the Japanese government's definition of SMEs varies not only according to the number of employees and total assets, but also according to the sector. Thus, in Japan, the number of employees required to be an SME depends on whether the firm is in manufacturing, wholesale, services or retailing. According to the Japanese definition of SMEs from Japan's Ministry of Economy, Trade and Industry (MITI), ${ }^{5}$ shown in Table 1, all of the approximately 100 potters working with traditional methods, either common potters or pottery masters, work in SMEs belonging to the ceramic, stone and clay product manufacturing industry with a number of regular employees between 1 and 25 workers (usually during firings they have additional temporary workers) and a capital lower than 300 million yen.

\section{Methodology}

In this research I have tried to understand how the producers of pottery for the tea ceremony think about the internationalization process and to identify the current strategies that they follow to achieve it. Thus, the article, in part, documents their experience and opinions regarding the importance that the inherent cultural factors of this pottery have on its internationalization and partly explores the link between the export of this product and Japanese cultural internationalization. This research focuses on Shigaraki city in Japan because Shigaraki is one of the so-called 'Six Old Kilns' of Japan (rokkoyo) ${ }^{6}$ that has kept up the old traditions of pottery production for the tea ceremony since the fifteenth century. 
TABLE 1: Small and Medium-Sized Enterprises: SME Definition

\begin{tabular}{|c|c|c|c|}
\hline \multirow[t]{2}{*}{ Industry } & \multicolumn{2}{|c|}{$\begin{array}{c}\text { Small and Medium Enterprise } \\
\text { (meet one or more of the following } \\
\text { conditions) }\end{array}$} & \multirow{2}{*}{$\begin{array}{l}\text { Of the small } \\
\text { enterprises } \\
\begin{array}{l}\text { No. of regular } \\
\text { employees }\end{array} \\
\end{array}$} \\
\hline & Capital & $\begin{array}{l}\text { No. of regular } \\
\text { employees }\end{array}$ & \\
\hline $\begin{array}{l}\text { 1) Manufacturing, construc- } \\
\text { tion, transport, other } \\
\text { industries }\end{array}$ & Up to $¥ 300$ million & Up to 300 & Up to 20 \\
\hline 2) Wholesale & Up to $¥ 100$ million & Up to 5 & Up to 5 \\
\hline 3) Services & Up to $¥ 50$ million & Up to 5 & Up to 5 \\
\hline 4) Retail & Up to $¥ 50$ million & Up to 5 & Up to 5 \\
\hline
\end{tabular}

Source: SME Agency and MITI, Japan, September 2010

To this end, a cross-sectional and descriptive study was carried out with the aim of identifying patterns of internationalization for the researched population (Hernández, Fernández \& Baptista 2007; Flick 2004). The research approach is inductive since it tries to identify ways to internationalize a specific type of product instead of establishing or testing the relationship between variables according to existing theories. I studied nine well-known master artists located in Shigaraki city, who produce pottery for the tea ceremony in the Anagama type of kiln. The master artists each work with their own kilns and can be considered an SME according to the Japanese definition. I identified the artists who fire pottery for the tea ceremony in Shigaraki from information from both the Shigaraki Art and Craft Ceramists Association and the Dentō Kōgeishi of Shiga Prefecture.

I confirmed that all nine produce this kind of pottery and that all of them were to some degree internationalized. Qualitative research techniques were used to collect the data. I conducted in-depth interviews with each of the nine well-known artists and observed them at their work places and visited the galleries of each artist. The same goes for collecting data in relation to the oral tradition, that is, the knowledge of this pottery that has been transmitted verbally across generations without written documents. I spent one month collecting data in the field, while living in the study of one of the artists. I also participated in pottery firings at three other Japanese potteries as well as spoke at and participated in several other activities in other Shigaraki potteries. Relevant secondary documentary sources were also used, such as pertinent literature on this kind of pottery production, documentation received from the individual artists and Shigaraki institutions, as well as information available on websites. 
I began by identifying the cultural factors related to the pottery for the tea ceremony. This information was used to design the in-depth interviews with the pottery artists that followed. The nine face-to-face in-depth interviews were semi-structured and took place in Shigaraki with the assistance of a Japanese potter and interpreter and consisted of three steps: first, I made a courtesy visit to the artists in order to see and talk briefly about their works. During a second visit, the in-depth interviewing based on a brief English-Japanese outline was done. A final brief visit was conducted so as to confirm that the information collected from each artist was correctly understood. The descriptive information gained from these interviews is summarized in the tables that follow. I began by asking about the artists themselves (age, experience, type of kiln, etc.). I then asked them about the cultural factors inherent in the pottery and the influence of Zen principles on this kind of pottery. Finally, I asked about their marketing strategies, internationalization strategies, promotional activities, and sales.

\section{Findings}

According to both the Shigaraki Art and Craft Ceramists Association and the Dentō Kōgeishi of Shiga prefecture, in Shigaraki city there are nine well-known master pottery artists that produce pottery for the tea ceremony with an Anagama kiln, eight of which hold the official title, two of them have been designated by the Shiga Prefecture as holders of 'Important Intangible Cultural Assets' and three of the nine produce pottery exclusively for the tea ceremony. At present there are about 350 kilns in Shigaraki, 50 of which are Anagama kilns, and approximately half of them belong to the nine artists studied. From an economic point of view, the pottery for the tea ceremony is only a small part of the ceramic sector but from a cultural and aesthetic point of view it is quite important. Table 2 summarizes the basic data on the potters interviewed. It is interesting to note that to become a well-known pottery artist in Japan requires many years of experience and for this reason the youngest master potter was 65 years old. The years of experience listed refers to the number of years dedicated to pottery, as some artists held other kinds of jobs before becoming master potters.

Concerning the market in Japan, there are two main types of buyers. The first type consists of people related to the different schools of the Japanese tea ceremony who use these objects in the ritual. The second 
TABLE 2: Basic Data of the Population Studied

\begin{tabular}{|l|c|c|c|c|c|c|c|c|c|}
\hline & $\begin{array}{c}\text { Artist } \\
\mathrm{n}^{\circ} 1\end{array}$ & $\begin{array}{c}\text { Artist } \\
\mathrm{n}^{\circ} 2\end{array}$ & $\begin{array}{c}\text { Artist } \\
\mathrm{n}^{\circ} 3\end{array}$ & $\begin{array}{c}\text { Artist } \\
\mathrm{n}^{\circ} 4\end{array}$ & $\begin{array}{c}\text { Artist } \\
\mathrm{n}^{\circ} 5\end{array}$ & $\begin{array}{c}\text { Artist } \\
\mathrm{n}^{\circ} 6\end{array}$ & $\begin{array}{c}\text { Artist } \\
\mathrm{n}^{\circ} 7\end{array}$ & $\begin{array}{c}\text { Artist } \\
\mathrm{n}^{\circ} 8\end{array}$ & $\begin{array}{c}\text { Artist } \\
\mathrm{n}^{\circ} 9\end{array}$ \\
\hline Age (years) & 67 & 81 & 66 & 65 & 83 & 84 & 87 & 84 & 82 \\
\hline Experience (years) & 44 & 60 & 32 & 46 & 63 & 60 & 70 & 66 & 66 \\
\hline Type of Kiln & A & A & A & A & A / N & A / N & A / N & A / N & A \\
\hline Internationalized & YES & YES & YES & YES & YES & YES & YES & YES & YES \\
\hline Languages spoken & JP/EN & JP & JP & JP & JP & JP & JP & JP & JP \\
\hline $\begin{array}{l}\text { Titles and prizes re- } \\
\text { ceived inside Japan }\end{array}$ & NO & YES & YES & YES & YES & YES & YES & YES & YES \\
\hline $\begin{array}{l}\text { Contact with schools } \\
\text { or masters of tea } \\
\text { ceremony }\end{array}$ & TM & STC & NO & STC & NO & NO & NO & NO & STC \\
\hline
\end{tabular}

Notes: A = Anagama kiln / $\mathrm{N}=$ Noborigama kiln

STC: School of Japanese Tea Ceremony / TM: Tea Masters

Source: Author

type is made up of Japanese art collectors. At present there are more than thirty schools focusing on the tea ceremony throughout Japan that use this pottery for demonstrations, exhibitions and official tea ceremonies.

Within Japan, the commercialization of this kind of pottery from the kiln to buyers is similar for all artists investigated. Table 3 shows different sales avenues used by artists to sell their pottery for the tea ceremony.

Art exhibitions and sales through department stores (depatō), as well as in their own galleries near the kilns, have a long tradition in Japan. Department stores enjoy great prestige and they have their own art galleries inside the stores. The renowned artists have their own galleries near their kilns and people visit them quite often despite the fact that these kilns are usually located in isolated places. Concerning e-commerce, Web portals such as Yahoo Japan! are in Japanese, and the virtual

TABLE 3: Commercialization Inside Japan

\begin{tabular}{|l|c|c|c|c|c|c|c|c|c|}
\hline & $\begin{array}{c}\text { Artist } \\
n^{\circ} 1\end{array}$ & $\begin{array}{c}\text { Artist } \\
n^{\circ} 2\end{array}$ & $\begin{array}{c}\text { Artist } \\
n^{\circ} 3\end{array}$ & $\begin{array}{c}\text { Artist } \\
n^{\circ} 4\end{array}$ & $\begin{array}{c}\text { Artist } \\
n^{\circ} 5\end{array}$ & $\begin{array}{c}\text { Artist } \\
n^{\circ} 6\end{array}$ & $\begin{array}{c}\text { Artist } \\
n^{\circ} 7\end{array}$ & $\begin{array}{c}\text { Artist } \\
n^{\circ} 8\end{array}$ & $\begin{array}{c}\text { Artist } \\
n^{\circ} 9\end{array}$ \\
\hline Own gallery-kiln & YES & YES & YES & YES & YES & YES & YES & YES & YES \\
\hline & & & & & & & & & \\
\hline Other galleries & ATB & NO & NO & NO & NO & NO & NO & YES & OCC \\
\hline & & & & & & & & & \\
\hline Department store & YES & YES & NO & YES & NO & YES & YES & YES & YES \\
\hline Own web site & & & & & & & & & \\
\hline & YES & NO & YES & YES & NO & NO & NO & YES & NO \\
\hline Web portal & NO & NO & YES & YES & NO & NO & YES & YES & NO \\
\hline
\end{tabular}

OCC: occasionally / ATB: at the beginning

Source: Author 
galleries that sell these articles online frequently do so without the artist's knowledge. These objects are bought and then re-sold but without openly representing a specific artist, and hence foreign buyers are not able to appreciate the cultural factors intrinsic to this pottery. Some of the artists have their own website, but in most cases it is dedicated to giving information but is not for sales.

The nine pottery masters agree that Zen principles are the main influence of the pottery used in the Wabicha tea ceremony, in practice since the fifteenth century. Additionally, all of them think that the cultural factors implicit in this pottery are the main motive to purchase the pottery for people related to Japanese schools of tea ceremony, collectors or those interested in the aesthetic of this pottery, but not for other kinds of buyers.

As shown in Table 4, none of the nine artists was able to provide the export income figures because they can only control the sales realized in their own galleries and the orders from galleries abroad. Artists think that it is very complicated to sell pottery for the tea ceremony in foreign markets, although five of them export regularly through art galleries located mainly in the USA and the European Union and through Japanese web portals specializing in pottery. However, all of them see themselves as internationalized because they sell to foreign buyers through their own galleries near the kilns in Japan and because all of them, except one, have carried out some type of activity in foreign markets, such as promotions in galleries, exhibitions and workshops. The main countries have been the USA, the European Union, Australia, South Korea, Indonesia, Hong Kong and Singapore.

The important point here is that some of the foreign buyers for galleries, who have been both at the kilns and in the galleries owned by the artists, according to the artists, have been able to appreciate the cultural factors implicit in this pottery and are willing to sell it in their own countries. Furthermore, most of those foreign buyers who have bought this pottery in the artists' galleries will continue buying this pottery through the Internet. According to the artists, people who have visited the kiln will usually buy pottery later from the artists' websites. Finally, four of the nine artists say that they have no direct or sustained contact with any school or master of the tea ceremony, although some of them frequently visit the kilns. Finally, most of the nine artists speak only Japanese. 
TABLE 4: Internationalization Strategies

\begin{tabular}{|c|c|c|c|c|c|c|c|c|c|}
\hline & $\begin{array}{c}\text { Art- } \\
\text { ist } \\
\mathrm{n}^{\circ} 1\end{array}$ & $\begin{array}{c}\text { Art- } \\
\text { ist } \\
\mathrm{n}^{\circ} 2\end{array}$ & \begin{tabular}{|c|} 
Art- \\
ist \\
$\mathrm{n}^{\circ} 3$ \\
\end{tabular} & $\begin{array}{c}\text { Art- } \\
\text { ist } \\
\mathrm{n}^{\circ} 4\end{array}$ & $\begin{array}{c}\text { Art- } \\
\text { ist } \\
\mathrm{n}^{\circ} 5\end{array}$ & $\begin{array}{c}\text { Art- } \\
\text { ist } \\
\mathrm{n}^{\circ} 6\end{array}$ & $\begin{array}{c}\text { Art- } \\
\text { ist } \\
\mathrm{n}^{\circ} 7\end{array}$ & $\begin{array}{c}\text { Art- } \\
\text { ist } \\
\mathrm{n}^{\circ} 8\end{array}$ & $\begin{array}{c}\text { Art- } \\
\text { ist } \\
\mathrm{n}^{\circ} 9\end{array}$ \\
\hline \multicolumn{10}{|l|}{ Type of web site owned: } \\
\hline $\begin{array}{l}\text { - Promotion \& Informa- } \\
\text { tion }\end{array}$ & YES & - & YES & YES & - & - & - & YES & - \\
\hline - E-commerce & YES & 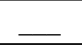 & $\mathrm{NO}$ & YES & $\overline{-}$ & - &  & YES & - \\
\hline - Languages displayed & $\begin{array}{l}\mathrm{JP} / \\
\mathrm{EN}\end{array}$ & - & JP & JP & - & - & - & JP & - \\
\hline \multicolumn{10}{|l|}{ Ways of selling abroad: } \\
\hline - Own Gallery in Japan & YES & YES & YES & YES & YES & YES & YES & YES & YES \\
\hline - Galleries abroad & YES & YES & YES & $\mathrm{NO}$ & $\mathrm{NO}$ & $\mathrm{NO}$ & YES & $\mathrm{NO}$ & YES \\
\hline - Universities & YES & $\mathrm{NO}$ & N0 & $\mathrm{NO}$ & $\mathrm{NO}$ & $\mathrm{NO}$ & $\mathrm{NO}$ & $\mathrm{NO}$ & $\mathrm{NO}$ \\
\hline $\begin{array}{l}\text { - Japanese Pottery Web- } \\
\text { Portals }\end{array}$ & NO & NO & YES & YES & $\mathrm{NO}$ & YES & YES & YES & $\mathrm{NO}$ \\
\hline \multicolumn{10}{|l|}{$\begin{array}{l}\text { Promotional activities } \\
\text { with no profit motive in } \\
\text { mind. }\end{array}$} \\
\hline $\begin{array}{l}\text { - Workshops and demos } \\
\text { abroad }\end{array}$ & YES & YES & NO & YES & NO & YES & $\mathrm{NO}$ & YES & $\mathrm{NO}$ \\
\hline $\begin{array}{l}\text { - Kiln firing in foreign } \\
\text { countries }\end{array}$ & YES & NO & NO & NO & NO & $\mathrm{NO}$ & $\mathrm{NO}$ & NO & $\mathrm{NO}$ \\
\hline $\begin{array}{l}\text { - Conferences and articles } \\
\text { abroad }\end{array}$ & YES & NO & NO & NO & NO & YES & $\mathrm{NO}$ & NO & $\mathrm{NO}$ \\
\hline $\begin{array}{l}\text { - Museums in foreign } \\
\text { markets }\end{array}$ & YES & YES & NO & NO & NO & $\mathrm{NO}$ & $\mathrm{NO}$ & YES & $\mathrm{NO}$ \\
\hline $\begin{array}{l}\text { - Classes given in Shiga- } \\
\text { raki }\end{array}$ & NO & YES & YES & YES & YES & YES & YES & YES & YES \\
\hline $\begin{array}{l}\text { - Conferences and articles } \\
\text { in Japan }\end{array}$ & YES & YES & YES & YES & YES & $\mathrm{NO}$ & YES & YES & YES \\
\hline - Museums inside Japan & YES & YES & YES & YES & YES & $\mathrm{NO}$ & $\mathrm{NO}$ & $\mathrm{NO}$ & YES \\
\hline - Movie and DVD & YES & $\mathrm{NO}$ & $\mathrm{NO}$ & $\mathrm{NO}$ & $\mathrm{NO}$ & $\mathrm{NO}$ & $\mathrm{NO}$ & $\mathrm{NO}$ & $\mathrm{NO}$ \\
\hline Export sales figures & UNK & UNK & UNK & UNK & UNK & UNK & UNK & UNK & UNK \\
\hline
\end{tabular}

$J P$ : Japanese / EN: English

UNK: Unknown

Source: Author

\section{Discussion}

\section{Internationalization Strategy}

All artists in this study said that the objective of internationalization is to sell their products in foreign markets, but as the pottery for the tea ceremony does not consist of commonly used objects, it would be better if its cultural factors and aesthetic were better known. They think that people interested in this kind of pottery should understand certain aspects related to it that are difficult to transmit beyond Japanese cul- 
tural boundaries. Therefore it would be better if they could perceive the implicit cultural factors of the pottery in a suitable environment, that is, to experience it, since printed material and DVDs cannot explain these factors accurately.

Although four of the nine artists examined do not export regularly, it should be noted that all of them consider their business to be internationalized because their pottery objects and their names are known outside of Japan both through foreigners visiting their kilns and galleries or through the websites of the galleries located in Japan, and/or attending the different activities executed inside Japan. Thus, in these cases the artists and their work could be considered internationalized but their SMEs are not.

I have earlier on in this article called this mode of starting the internationalization process 'reverse prior phase' with the intention of differentiating this from passive exports or domestic sales. The reason for this distinction is that 'reverse prior phase' implies doing several activities, such as workshops and demonstrations abroad to raise foreign buyers' interest, or design courses or conferences so that potential buyers can get a deeper insight into this particular type of pottery. This is to ensure that the Japanese cultural factors are becoming better known outside Japan. Therefore, this phase does not consist in waiting passively for foreign buyers to go to Japan to buy Japanese pottery for the tea ceremony.

I argue that this 'reverse prior phase' seems to be suitable to begin the internationalization process for SMEs, whose business activities are linked to native and cultural factors and have a limited and personalized line of production, as is the case of Japanese pottery production for the tea ceremony. However, this approach would not be appropriate for other types of ceramic segments such as industrial ceramics or ceramics for everyday use since they have a large output of similar products that are not manufactured by culturally specific production processes.

In fact, this previous stage is not exclusive to this kind of pottery since it can also be identified in other sectors that have a local component attached to it, such as the quality wine business. Thus, some wineries, in France and Spain for example, try to attract potential foreign wine store owners, wine connoisseurs and specialized consumers by inviting them to visit their vineyards and experience their wine. They see this as a better way to promote their products than using brochures, DVDs, international fairs or commercial samples, since during the visit guests are able to see the real wine-making process in detail, to know the methods and philosophy of the winery and to taste some of their wines. 
In this way the producers of pottery for the tea ceremony are interested in attracting foreign visitors interested in this kind of pottery to Shigaraki city as a way of initiating their internationalization process, instead of other less suitable models for this kind of product, such as exporting through foreign importers, distributors or by participating in international fairs. These foreigners cannot be classified merely as tourists as they visit the kilns and take part in activities to learn about this particular kind of pottery. Furthermore, they acquire pottery objects in the artists' galleries near the kilns and take them back home. In this way, the artists' names are becoming known and the history, meaning and philosophy of the pottery is gaining an audience outside of Japan, although the pottery SMEs cannot be considered internationalized at this point.

\section{Importance of Cultural Factors Implicit in Japanese Pottery for the Tea Ceremony}

According to the artists, foreign collectors and buyers that appreciate Japanese pottery for the tea ceremony have had some previous contact with Japanese culture. Nevertheless, the artists think that cultural factors are important for buyers that know and practice the tea ceremony, but not for other buyers, such as collectors. Of course, people related to the tea ceremony already know the cultural factors inherent in this pottery and can thus appreciate it and are willing to pay a high price for it. Nevertheless, according to the artists, collectors probably are willing to buy these expensive objects precisely because of their uniqueness and high value although they do not necessarily know about the origin of its aesthetic nor understand the implicit cultural meaning. Perhaps this knowledge is less important for casual buyers than for retailers such as art gallery owners. Four of the artists say that some foreign buyers who have visited their kilns and the galleries near to the kilns have become their overseas point of sale. Thus, these potential retailers are foreigners that travel to Japan to visit kilns and artists' galleries for direct understanding and to obtain this pottery for resale in their respective countries, usually in galleries. Obviously, this kind of understanding can be gained more easily inside Japan with the artists at the local production sites than abroad through brochures and DVDs since it is in this context that the cultural encoding takes place thus allowing the buyer (usually gallery owners or specialized collectors) to understand the products' special attributes. Promotion of products across borders and contact with potential overseas retailers and customers are barriers that impede the internationalization of SMEs, especially for enterprises that are too 
small to have someone dedicated to these activities. Additionally, the difficulty is perhaps even greater for SMEs producing goods with cultural factors ingrained in them that are not well known in foreign countries. In this case, the 'reverse prior phase' can be a suitable way of starting their process of internationalization. There is no doubt that this mode is expensive for potential foreign retailers but it could be worthwhile for them to obtain a clear advantage in their gallery abroad.

\section{Pottery for the Tea Ceremony, Exports and the Internationalization of Japanese Culture}

The Japanese know and understand the significance of these special objects because they are immersed in their culture and therefore this pottery is highly appreciated inside Japan. In foreign markets, however, most people are unaware of its cultural factors. However, it seems that it is possible to sell products with an ingrained set of cultural and local values on foreign markets, since there are five pottery artists who export regularly to the USA and European Union markets.

But do exports of products with Japanese cultural factors lead to the internationalization of Japanese culture? The artists in this study believe that a relationship exists between the exports of this pottery and the knowledge of some aspects of Japanese culture outside Japan. They assume that knowledge of any aspect of Japanese culture, although not related directly to pottery for the tea ceremony, may increase the interest in this kind of pottery. However, it is questionable whether the mere purchase of these items transmits cultural knowledge. On the contrary, it would be necessary to have previous knowledge of the significance behind this pottery in order to be able to appreciate it. But it seems possible that products with a cultural and local meaning, produced in very small quantities and with a high value, can be internationalized applying a strategy that differs from conventional export strategies, although a 'reverse prior phase' could be more expensive at the beginning and less suitable for other kinds of business activities. In turn, once these products are exported, it seems probable that more people in foreign markets will begin to get interested and thus learn about the cultural elements related to this particular kind of pottery. However, exports of Japanese pottery objects for the tea ceremony by themselves do not lead to Japanese culture internationalization. 


\section{Conclusion}

The purpose of this research is to make a contribution to the literature on SME internationalization strategies by introducing the specific practices employed by the producers of pottery for the tea ceremony in Shigaraki. One limitation of the present study is the limited number of cases (nine) investigated. A consequence is that the results and conclusions of this paper cannot be generalized and thus more research is needed in other pottery areas of Japan to be able to compare the results. A second limitation is that the results are limited to the internationalization strategies followed by the producers of this particular kind of pottery and cannot be applied to other SMEs in the ceramic industry that manufacture industrial products that are produced in large quantities via industrialized processes. Despite these limitations, the mode that I have called 'reverse prior phase' could be employed to study the internationalization strategies of other kinds of goods and services with implicit cultural features similar to those discussed for the Japanese pottery for the tea ceremony. Although small in scope, this research contributes to the broader field of SME internationalization strategies by offering an insight into one type of product that cannot internationalize through conventional strategies. Identifying the 'reverse prior phase' used by these SMEs trying to market this type of culturally bound product may be the first step toward a new perspective on this strategic process.

Gloria García received her Ph.D. (2012) in Economics from ICADE, Comillas University of Madrid. She is Assistant Professor of Internationalization Strategies, Business with East and Southeast Asia and Intercultural Negotiation. Gloria is Director of the Master's degree in International Business Management at ICADE Business School. She was Visiting Researcher at the Institute of Social Science (ISS), University of Tokyo. Her research interests include enterprise internationalization strategies, Japan and Asian culture on business and the differentiation to compete and intercultural business negotiation.Email: gloria@sirte-internacional.com

\section{NOTES}

1 OECD: Detailed Benchmark Definition of FDI: 3rd ed. (BD3), Paris, 1996. See also, IMF: Balance of Payments Manual. 5th ed. Washington, DC, 1993.

2 UNCTAD, 2002. www.unctad.org.

3 OECD-APEC, 'Removing barriers to SME access to international markets'. November 2006. 
4 The data are from the Shigaraki Art and Craft Ceramists Association and from Dentō Kōgeishi of Shiga prefecture. 'Dentō Kōgeishi' is a title given by the Japanese Government to artists, meaning 'Master of Traditional Arts'.

5 Article 2 of the Small and Medium-Size Enterprise Basic Act, Small and Medium Enterprise Agency and Ministry of Economy, Trade and Industry (MITI), September 2010.

6 The so-called Six Old Kilns of Japan (rokkōyo) are Shigaraki, Seto, Bizen, Echizen, Tanba and Tokoname.

\section{REFERENCES}

Daniels, J. D., I. H. Radebaugh, and D. P. Sullivan. 2010. International Business. Environments and Operations. Essex: Prentice Hall.

García, G. 2012. Estrategias de Internacionalización de la Empresa: Cómo Hacer Negocios Internacionales. Madrid: Pirámide.

Holmlund, M., S. Kock, and V. Vanyushyn. 2007. Small and Medium Enterprises' Internationalization and the Influence of Importing on Exporting. International Small Business Journal 25(5): 459-477.

Juniper, A. 2003. Wabi Sabi, The Japanese Art Of Impermanence. Boston: Tuttle Publishing.

Krugman, P., and M. Obstfeld. 1999. Economía Internacional. Madrid: McGraw Hill.

Lu, J. W., and P. W. Beamish. 2006. SME Internationalization and Performance: Growth vs. Profitability. Journal of International Enterpreneurship 4(1): 24-48.

OECD-APEC. 2006. 'Removing barriers to SME access to international markets'. OECDAPEC Global Conference, 6-8 November 2006, Athens, Greece.

Rugman, M., and S. Collinson. 2009. International Business. Essex: McGraw Hill.

Rugman, M., and A. Verbeke. 2009. 'Environmental Policy and International Business'. In The Oxford Handbook of International Business, A. M. Rugman (ed.). Oxford: Oxford University Press.

Su, M. Z., and R. Poisson. 2000. Utilisation of Strategic Alliances in the Processes of Internationalization: An Empirical Study of Small and Medium-Size High-Tech Enterprises. Québec: Laval University.

Suzuki, D. T. 2009. Zen and Japanese Culture. Tokyo: Kodansha International.

Tanaka, S. 2000. The Tea Ceremony. Tokyo: Kodansha International.

Yanagi, S. 1989. The Unknown Craftsmen. Tokyo: Kodansha International. 